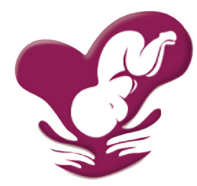

Published By : PERINASIA The Indonesian Society of Perinatology

\section{Knowledge, attitude, and practice of Kangaroo Mother Care among health providers in Depok General Hospital}

CrossMark

\author{
Astri Fauziyah', Hadi Pratomo ${ }^{2 *}$, Karina Samaria ${ }^{3}$
}

'Alumna of the undergraduate program of Faculty of Public Health, Universitas Indonesia

${ }^{2}$ Professor of Faculty of Public Health, Universitas Indonesia

${ }^{3}$ Alumna of the postgraduate program of Faculty of Public Health, Universitas Indonesia
*Corresponding to:

Hadi Pratomo ; Department of Health Education \& Behavioral Sciences, Faculty of Public Health, Universitas Indonesia; hadi.pratomo@ui.ac.id pratomohadi@gmail.com

Received: 2021-10-10

Accepted: $2021-11-26$

Published: 2021-11-30

\section{ABSTRACT}

Introduction: Low birth weight infants contribute to neonatal deaths. Kangaroo mother care (KMC) is a treatment with various benefits as an alternative to an incubator. In Depok General Hospital, its implementation was not yet optimal. This study aimed to assess kangaroo mother care knowledge, attitude, and practice among health providers.

Methods: This descriptive study with a cross-sectional approach was conducted from November to December 2015 at Depok General Hospital. The population was all health providers in the study site. This study used total sampling (37 persons). The inclusion criteria were: health providers of Depok General Hospital who worked in the perinatology, delivery, roomingin rooms, and obstetric polyclinic, had a minimum of 6 months working experience, agreed to become respondents. The exclusion criteria were: on work leave during the study period, on study assignment without working. The data were collected using a questionnaire. Univariate analysis was conducted using SPSS.

Result: The mean age of respondents was 31.38 years, ranging from 23-41 years. The average working experience was 7.95 years. All respondents were female, $81.1 \%$ graduated from Diploma III, and $72.97 \%$ had experienced or trained in KMC. About $75.7 \%$ of respondents had good knowledge of KMC, $51.4 \%$ had a positive attitude towards KMC, and $64.9 \%$ had a low level of KMC practice.

Conclusion: The majority of the respondents had good knowledge of KMC, around half had a positive attitude towards KMC, and more than half had a low level of KMC practice. Training, facilities, written SOP, and management commitment for KMC are needed for successful KMC implementation.

Keywords: attitude, health providers, knowledge, practice, kangaroo mother care

Cite This Article: PFauziyah, A., Pratomo, H., Samaria, K. 2021. Knowledge, attitude, and practice of Kangaroo Mother Care among health providers in Depok General Hospital. Indonesian Society Of Perinatology 2(2): 32-35. D0I: 10.51559/ inajperinatol.v2i2.15

\section{INTRODUCTION}

The infant mortality rate in Indonesia in 2013 was 34 per 1000 live births, still under the target of Millennium Development Goals. Neonatal mortalities contributed to $56 \%$ of the number. One of the main causes of neonatal deaths is Low Birth Weight in Infant (LBWI). LBWI is a newborn weighed less than 2500 grams at birth regardless of gestational age. ${ }^{1}$ In general, LBWIs do not yet have a mature body defense system to adapt to the environment. They tend to be hypothermic due to thin subcutaneous fat. ${ }^{2}$ To maintain a stable body temperature, LBWIs need interventions until they develop optimal function. Incubators are widely used for this purpose, but they require high costs, are available in limited numbers, and are frequently used for more than one baby, thus increasing the risk of nosocomial infection and cause separation of mother and newborn. ${ }^{3}$

Innovation has been found as an alternative to an incubator, known as Kangaroo Mother Care (KMC). KMC is a treatment for LBWI by making direct contact (skin-to-skin) between mother and baby, where the mother uses her body temperature to warm her baby. KMC can also improve mother-child bonding and increase a child's growth and development. ${ }^{4}$ Knowledge and skills of health providers are needed to ensure the family's ability in doing KMC. Trained nurses and midwives hold a vital role in assisting families of LBWI.,

Depok General Hospital serves as a type C government hospital that receives referrals from first-tier health services. In January-August 2015, there were 38 LBWI cases, increasing from 22 cases in the previous year. LBWIs were still managed mainly with incubators. A preliminary study through an interview with the head of perinatology indicated that KMC implementation in this hospital was not yet optimal, but education on KMC was given to LBWI families before hospital discharge. Therefore, this study aimed to assess the knowledge, attitude, and practice of KMC among related health providers in Depok General Hospital. 


\section{METHODS}

This study was a descriptive study with a cross-sectional approach, from November to December 2015 at the perinatology room, delivery room, rooming-in rooms, and obstetric policlinic of the Depok General Hospital. The population was all health staff assigned in the mentioned rooms with a total number of 37 persons. This study used total sampling due to the small population. The inclusion criteria were: (1) health staff of Depok General Hospital who worked in the perinatology room, delivery room, rooming-in rooms, and obstetric policlinic; (2) had a minimum of 6 months working experience; (3) agreed to become respondents and signed the informed consent. The exclusion criteria were: (1) on work leave during the study period, (2) on study assignments without working.

The data were collected using a questionnaire about age, sex, working experience, experience or training related to KMC, LBWI management, or neonatal care; knowledge, attitude, and practice of $\mathrm{KMC}$. The questionnaire had undergone validity and reliability tests. The collected data were edited, coded, processed, cleaned, and analyzed. Univariate analysis was conducted to see the distribution and frequency of each variable.

This study complied with the ethical principles of using humans as a subject of the study, namely: (1) respect for human dignity, by giving informed consent; (2) respect for privacy and confidentiality, by using code instead of respondent's name; (3) respect for justice and inclusiveness, by giving an explanation on study process and fair treatment to all respondents; (4) balancing harms and benefits of the study. In addition, it also fulfilled the ethical principles as described in the Helsinki Declaration. $^{7}$

\section{RESULTS}

Data were collected from 37 respondents. The characteristics of respondents are shown in Table 1.

On average, the respondents were in their 30s with around eight years of working experience. All of the respondents were females. Most of them attained Diploma III, a vocational graduate certification, and had experience or received training in KMC.

The knowledge, attitude, and practice of KMC are shown in Table 2. The results for each variable were classified into two categories. The level of knowledge in KMC was classified as low if the total score was below the mean/median value. It was considered as good if the score was $\geq$ mean/median value. The same classification also applied to the practice of KMC. The attitude of respondents towards KMC was classified as negative if the total score was below the mean/median value. It was classified as positive if the score was $\geq$ mean/median value.

The majority of respondents had good knowledge of KMC but were low in practice. As for the reasons, $29.7 \%$ of

Table 1. The characteristics of respondents

\begin{tabular}{lc}
\multicolumn{1}{c}{ Variable } & Frequency (Percentage) \\
\hline Age & \\
Mean \pm SD & $31.38 \pm 4.2$ years \\
Min-Max & $23-41$ years \\
Working experience & \\
Mean \pm SD & $7.95 \pm 4.4$ years \\
Min-Max & $1-22$ years \\
Sex $\quad$ & $0(0)$ \\
Male & $37(100)$ \\
Female & \\
Level of education & $30(81.1)$ \\
Diploma III (D3) & $7(18.9)$ \\
Bachelor (S1) & $10(27)$ \\
Experience/Training in KMC & $27(73)$ \\
Never &
\end{tabular}

Table 2. Knowledge, attitude, and practice of Kangaroo Mother Care

\begin{tabular}{ccc} 
Variables & Frequency & Percentage \\
\hline Knowledge & 9 & $24.3 \%$ \\
Low & 28 & $75.7 \%$ \\
Good & & \\
Attitude & 18 & $48.6 \%$ \\
Negative & 19 & $51.4 \%$ \\
Positive & & \\
Practice & 24 & $64.9 \%$ \\
Low & 13 & $35.1 \%$ \\
Good & 13 \\
\hline
\end{tabular}

respondents stated that the hospital had not yet implemented KMC, there was no Standard Operating Procedure (SOP), and no facilities for KMC. The number of respondents who had a positive attitude towards KMC was only slightly above the number of respondents with a negative attitude.

\section{The characteristics of respondents}

The respondents' mean age was around 32 years with 23 years as the youngest and 41 years as the oldest. Notoatmodjo ${ }^{8}$ stated that age influences perception and mindset. With increasing age, perception and mindset will also develop and improve. But, in certain ages, the development will

\section{DISCUSSION}


not be as fast as younger ages. According to Kozier ${ }^{9}$, individuals enter the stage of young adulthood at 20-40 years. At this age, individuals are required to take on new roles in the workplace, home, and community. They also develop interests, values, and attitudes that are associated with that role. They have maturity and greater ability to think and work. Age 41-65 years is the period of middle age, where intellectual and cognitive abilities do not undergo much change. From these descriptions, it can be concluded that increasing age may cause increasing knowledge.

All of the respondents were females. This condition is following the first history of the nursing profession started by Florence Nightingale when this profession was considered based on motherly love. Sex is said to influence the perspective on the service given. Females tend to be more detailed than males. ${ }^{10}$ The level of education also participates in shaping the mindset, perception pattern, and attitude of decision-making in health behavior. Formal education contributes to the increase of productivity or performance of nurses. Education provides knowledge directly with the execution of tasks and develops themselves and the ability to use available facilities to smooth the task. The hospital will not get satisfactory results without adequate education and training for nurses. ${ }^{11}$

Approximately $73 \%$ of respondents have received KMC training. Christensen and Kenney ${ }^{12}$ wrote that when nurses have more experience, they will have more knowledge about themselves, health clients, and interpret certain information and perform nursing actions. But, Rahmah, Lasmini, and Rahmatini ${ }^{13}$ stated in their study that training did not show an effect on good practice if health providers did not repeatedly learn and did the training materials. The study by Solomon and Rosant ${ }^{14}$ showed that experience or training in KMC could address misunderstandings and gaps in knowledge. KMC training should emphasize the skills necessary to carry out safe and effective KMC practices.

\section{Knowledge of KMC}

The study showed that the majority of respondents had good knowledge. Sufficient knowledge can be influenced by education and closely related to behaviour or practice. Knowledge is one component of nursing care. Knowledge and skills related to KMC are needed because $\mathrm{KMC}$ is an intervention for LBWI, which needs medical support. ${ }^{6}$ Applied knowledge will increase along with age and experience. Health providers' knowledge will ease in building mutual trust with clients and in giving care. ${ }^{15}$ Due to the importance of KMC knowledge, training opportunities should be created to address misconceptions and knowledge gaps. Training should emphasize the facts and abilities related to safe and effective KMC practice and include a hands-on experience. ${ }^{14}$

A study by Martha et al. ${ }^{16}$ in 2017, also held in the Depok area, gave supporting evidence that KMC training can significantly increase knowledge of health providers. But this study also noted that knowledge of KMC could be obtained not only through formal training. Transfer of knowledge could also be done from the trained health providers to the untrained health providers informally through their daily work together, especially in units/ rooms requiring direct contact with mothers and babies (in-patient rooms, perinatology, rooms, etc.). In a qualitative study among health providers from Koja and Karawang District Hospitals, Pratomo et al. also gave the conclusion that health providers can obtain sufficient general knowledge from their own experiences and observations to work in a KMC related service. Their health-related educational backgrounds supported this. ${ }^{17}$

\section{Attitude towards KMC}

About $51.4 \%$ of respondents had a positive attitude towards KMC. According to Notoatmodjo ${ }^{8}$, attitude is an emotional reaction or response towards a stimulus that is more of a personal assessment or evaluation and is continued with a tendency to do or not to do something. Attitude tends to give a positive or negative response towards an object and a change of attitude is first shown through compliance. Attitude is influenced by personal experience, the influence of others, and influence of culture. Davy and Van Rooyen in Solomon and Rosant ${ }^{14}$ wrote that attitudes of health providers are among the most important factors which determine how parents perceive their KMC experience.

\section{Practice of KMC}

Depok General Hospital had not yet optimally delivered KMC in LBWI treatment. The majority of respondents had a low level of KMC practice. Based on the study result, the reasons were the hospital had not yet implemented KMC, there was no SOP and facilities for KMC. Besides health providers' knowledge and skills, a successful KMC implementation requires commitment from management, dedicated trained staff, provision of facilities, and also written protocols. ${ }^{14}$

This study has several limitations. From 18 questions on knowledge, only 6 were valid based on the validity test. Other questions were unable to be added due to time limitations. Thus, the questions on knowledge only include LBWI care, benefits, components, and implementation of KMC. These questions were valid but not yet confirmed for reliability. The respondents filled the questionnaire not on the same day. This gave chance for information exchange. The questionnaire was subjective, therefore, the quality of data depended on the honesty and seriousness of respondents.

\section{CONCLUSION}

The characteristics of respondents were: in the period of young adulthood to middle age, the average working experience was 7.95 years, all respondents were female, and the majority graduated from Diploma III and had experienced or trained in KMC. The majority of respondents had good knowledge of KMC, around half of them had a positive attitude towards KMC, and more than half had a low level of KMC practice. Training, facilities, written SOP, and management commitment for KMC are needed for successful implementation. More studies are needed, especially to measure KMC knowledge in broader aspects. 


\section{DISCLOSURES}

\section{Funding}

There is no funding for this study. This study was an undergraduate thesis of the first author.

\section{Conflict of Interest}

All authors declare there is no conflict of interest.

\section{Ethic Approval}

This study had been ethically approved by ethical commission of Faculty of Public Health, Indonesia University with ethical clearance number: S-3574/UN2.F10.D/ PDP.04.00/2021

\section{Author Contribution}

AF conceptualized, designed the study, conducted data collection, data analysis, and wrote the thesis. KS reviewed the thesis, provided new literature for the study, and prepared a draft of the manuscript according to the guideline. HP guided data analysis, reviewed, approved the final manuscript and served as corresponding author.

\section{ACKNOWLEDGMENTS}

The authors would express sincere thanks to Director of the Depok General Hospital for permitting this study. In addition, the authors would express sincere thanks to all respondents who had participated in this study and to Mr.Fikri Wijaya from the Library of Faculty of Public Health, Universitas Indonesia for giving the access to the softcopy of this thesis.

\section{REFERENCES}

1. Kementrian Kesehatan. Profil Kesehatan Indonesia Tahun 2013. Jakarta: Kementerian Kesehatan RI. 2014. 507 p.

2. Deswita, Besral, Rustina Y. Pengaruh Perawatan Metode Kanguru terhadap Respons Fisiologis Bayi Prematur. Kesmas Natl Public Heal J. 2011;5(5):227.

3. Perinasia. Perawatan Bayi Berat Badan Lahir Rendah dengan Perawatan Metode Kanguru. Jakarta; 2005.

4. IDAI. Perawatan Metode Kanguru (PMK) Meningkatkan Pemberian ASI. 2013.

5. Kusumawati NN. Gambaran Tingkat Pengetahuan Perawat Tentang Perawatan Metode Kanguru di RSAB Harapan Kita. Universitas Indonesia; 2011.

6. Indonesia DKR. Pedoman Pelayanan Kesehatan Bayi Berat Lahir Rendah dengan Perawatan Metode Kanguru di Rumah Sakit dan Jejaringnya. Jakarta: Departemen Kesehatan Republik Indonesia; 2009.

7. World Medical Association. Declaration of Helsinki, Ethical Principles for Medical Research Involving Human Subjects. Bulletin of the World Health Organization. 2001;79(4):373-4.

8. Notoatmodjo S. Promosi Kesehatan \& Ilmu Perilaku. Jakarta: PT. Rineka Cipta; 2007.

9. Kozier B. Buku Ajar Fundamental Keperawatan: Konsep, Proses, dan Praktik. 7th, Volume ed. Jakarta: EGC;
10. Oroh ME, Rompas S, Pondaag L. Faktor-faktor yang Berhubungan dengan Tingkat Kepuasan Pasien Rawat Inap terhadap Pelayanan Keperawatan Di Ruang Interna RSUD Noongan. E-Jurnal Keperawatan. 2014;2(2).

11. Faizin A, Winarsih. Hubungan Tingkat Pendidikan dan Lama Kerja Perawat Dengan Kinerja Perawat di RSU Pandan Arang Kabupaten Boyolali. Ber Ilmu Keperawatan ISSN 1979-2697. 2008;1(3):137-42.

12. Christensen PJ, Kenney JW. Proses Keperawatan Konseptual. Edisi 4. Jakarta: EGC; 2009.

13. Rahmah N, Lasmini PS, Rahmatini R. Hubungan Karakteristik dan Tingkat Pengetahuan Petugas Imunisasi terhadap Praktik Penyimpanan dan Transportasi Vaksin Imunisasi di Tingkat Puskesmas Kota Padang Tahun 2014. J Kesehat Andalas. 2015;4(3):91724.

14. Solomons N, Rosant C. Knowledge and attitudes of nursing staff and mothers towards kangaroo mother care in the eastern subdistrict of Cape Town. South African J Clin Nutr. 2012;25(1):33-9.

15. Ulfah R, Sulisno M. PENGETAHUAN PERAWAT TENTANG KONSEP KEPERAWATAN HOLISTIK. J Nurs Stud. 2012;1(1):157-62.

16. Martha E, Amelia T, Endah C, Jamiatun I, Pratomo H. Implementation of The Kangaroo mother care ( KMC) program in Depok Regional General Hospital and two PONED Public Health Centers in Depok, Indonesia. J Neonatal Nurs. 2020;(December).

17. Pratomo H, Amelia T, Nurlin F, Adisasmita AC. Knowledge and perceptions of kangaroo mother care among health providers: a qualitative study. 2020;63(11):433-7.

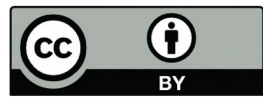

This work is licensed under a Creative Commons Attribution 